\title{
Understanding the importance of ethos in composing the "everyday" new literacies classroom
}

\author{
JAMES NAHACHEWSKY \\ University of Victoria
}

\begin{abstract}
This article examines the impact of a senior English teacher's ethos in composing, with her students, a new literacies classroom. This is a paradigm case where ever-changing technical stuff and a new ethos are encouraged in the literacy events of the classroom context. Utilizing a metaphor of 'classroom as text', we better understand the importance of the teacher's own literacies, and her role as co-author of new, situated classroom literacies. In this case, language and literacy teaching becomes tangential through multitextual readings and compositions that enact an ellipsis where certain previously privileged texts and approaches are omitted. In this way, through a reciprocal relationship, the teacher fosters rather than defines her students' emergent literacies and critical thinking development. In turn, the students influence their teacher's conceptions of what it means to be literate; what textual readings and compositions are meaningful to their situated language learning in digital times.
\end{abstract}

The time for thinking about the Internet and digital literacies as revolutionary has passed. Books have been published, careers made, and computer networks installed. Now we are ready to move onto an even more difficult concept: How do we think about the everyday? (Leander, 2008, p. 33)

\section{Introduction: Every day is a new situation}

What happens to high school English teachers' pedagogy and students' literacy learning when new digital-based interactive reading and writing technologies are introduced into the English language arts (ELA) classroom? I have been asking and answering that question, as both an educator and researcher within a new literacies framework, over the past ten years (Nahachewsky, 2003; 2005; 2007; 2012; Nahachewsky \& Slomp, 2009; Patterson, Stokes-Bennett, Siemens, \& Nahachewsky, 2010). I have inquired into the "everyday" usage of online writing spaces, multi-modal blogs, podcasts, eReaders, and most recently iPads in middle, secondary, and tertiarylevel literacy classrooms. Perhaps the most important reason that I have been examining new literacies during the past decade is that I take to heart (for there is much heart required in the work that we do as literacy educators) Merchant's (2008) challenge that, "... it is hard for us to know which dispositions, values and practices will remain important and which new ones may be required" (p. 751). We - whether "we" are education students, teacher-educators, literacy researchers, policy-makers, or school administrators - need to make clearer sense of the personal and social reading, writing, and meaning-making practices in the fractured spaces, both physical and cyber, of the 
everyday language and literacy classroom. We need a better understanding, in the words of one teacher, "... of what texts and textual practices are important to hold on to, and which can be let go of" (Nahachewsky, 2010, p. 216).

Throughout the past ten years I have found the "everyday" (Leander, 2004) of literacy classrooms to be anything but mundane. New situated literacy practices are demanded by curricula. They can be created and forgotten as quickly as the new technologies that afford them, often at a dizzying rate. As another teacher declared to me, "I feel that teaching ELA is like conducting an experiment with too many variables" (Nahachewsky, 2010, p. 223). Every day, then, presents deictic change. Indeed, it is important to realize, as Leu et al., (2004) state, “... when we use technology in new ways, we also transform the technology itself, creating additional new literacies in the process" (p. 1593). New technologies can certainly affect new literacy practices because "the relationship between literacy and technology is transactional" (Larson, 2012, p. 281). But it is equally, if not more important, to understand the ethos, or the "kinds of values, emphases, priorities, perspectives, orientations and sensibilities" (Lankshear \& Knobel, 2007, p. 9). These are essential for new literacies to develop and flourish in everyday classroom teaching practice and students' literacy development. This article then, examines one high school English teacher's ethos - with accompanying tensions and affordances - and its impact on composing a new literacies classroom with her students.

\section{Theoretical perspectives}

\section{Teaching language and literacy}

Teaching language and literacy in high school is a complex endeavour that involves the identification and scaffolding of particular curricular-defined learning outcomes that address students' cognitive, affective and psychomotor domains. In English language arts, arguably a "contentless" subject discipline, teachers are asked to engage students through a variety of text types - including poems, novels, plays, essays, movies, magazine advertisements, and web pages to name just a few - that elicit aesthetic and efferent responses in those same readers/viewers/listeners. Besides encouraging a culture of thoughtful and critical consumption by its students, the ELA subject discipline demands that those same students produce a diverse manner of communications including writing, speaking, and representing for a variety of audiences and purposes.

Complicating the already complex process of teaching ELA is the ever-expanding universe of text - both in form and content -and evolving notions of what it means to be literate in a rapidly changing and multi-modal world. Arguably, at no other time have teachers' textual stances (the choices they make regarding the selection of text types) or their pedagogy (how they support their learners' mastery of a wide variety of learning outcomes through the strategies and practices they bring to the learning contexts of brick and mortar, page, and screen) been more important.

Teaching high school English language arts is also a process of relationships among the teacher, the curriculum, and the students. Added to these inter-relationships and clearly impacting their textual and pedagogical choices is the teacher's intrarelationship - who the teachers see themselves to be and who they want to be; their conceptions of literacy; and who they want their students to become as readers, writers, speakers, listeners, viewers, and representers. Sperling (2004) notes that research rooted 
in socio-cultural theories often "uncovers the contradictions by which individuals involved in the enterprises of schooling appear to be defined, motivated, and constrained" (p. 234). There are many contradictions in contemporary ELA classrooms where new literacies struggle to emerge.

\section{The role of text}

Text has been, and continues to be, central to high school English language arts (ELA) curricula and teachers' pedagogy. Knobel and Lankshear (2007) suggest that "[t]he book in no way comprises the text paradigm in the emerging digital media space. Indeed, there is no text paradigm" (p. 14). Yet, generations of pre-service and practicing teachers, including today's, have held the book as a textual paradigm. Those who enter language and literacy teacher education programs and those who continue to teach are ordered by "book-mediated social relations of control and power, as between author and readers, authorial voice as the voice of expert and authority, teacher/expert and student/learner..." (Knobel \& Lankshear, 2007, p. 13). Contrary to Lankshear's and Knobel's claim that there is no text paradigm, the book remains as an organizing factor in both the new technologies and the literate practices of teachers and students. This is evident as "reading and writing frequently occur in a range of literacy contexts outside school. However, only reading novels on a regular basis outside of school is shown to have a positive relationship to academic achievement as measured by school grades" (Moje, Overby, Tysvaer \& Morris, 2008, p. 107). Larson (2012) further notes that "ebooks accessed on digital reading devices such as Kindles or Nooks are mostly linear... just as traditional print texts require students to use a wide range of comprehension strategies based on both reader factors and text factors, so, too, do digital texts" (p. 281). So what is required to compose a new literacies classroom?

\section{New technical and new ethos stuff}

Drawing from Lankshear and Knobel (2006), Lewis (2007) reminds us "new literacies aren't new unless they have both new 'technical stuff' and new 'ethos stuff"" (p. 230). The "new technical" aspect recognizes that "more broadly conceived notions of literacy and literacy instruction are being defined by change in even more profound ways as new technologies require new literacies to effectively exploit their potentials" (Leu, Kinzer, Coiro, \& Cammack, 2004, p. 1570). As Knobel and Lankshear (2007) write, "the significance of the new technical stuff has mainly to do with how it enables people to build and participate in literacy practices" that are different from conventional literacies (p. 7). "New ethos stuff" includes changed "...values, sensibilities, norms and procedures and so on from those that characterize conventional literacies" (Knobel \& Lankshear, 2007, p. 7). When both the new technical and new ethos stuff is present in a literacy event then one has a paradigm case, rather than peripheral case of new literacies (Knobel \& Lankshear, 2007).

The "new technical stuff" is continually changing in our consumptive society and includes single and multipurpose communication platforms such as smart phones, iPads, digital cameras, the Internet and so forth. Schools often struggle to populate classrooms with the latest new technical stuff that high school students use in their home and work lives. This can be due to high costs, maintenance, and sustainability. Some provincial Education Ministries, such as Alberta's, have gone through large-scale implementations 
of new technical stuff including laptops, smart-boards, and more recently localized purchase and implementation of iPads.

We know that technology and literacy can have a correlative relationship. Even when emergent "new technical stuff " is present in the classroom, though, it does not determine the presence of new literacies practices. Researchers such as Leander (2004) have noted that "these new literacies and ways of knowing remain absent from most classrooms. Many education administrators, teachers, teacher educators, and academics seem largely unaware of them. Some actively oppose them" (p. 16). In the 2012 Government of Alberta School Technology Sector report, iPads: What are we learning?, it is noted that despite their intensely personalized design, iPads "can also be used to foster lower levels of cognitive engagement effectively digitizing drill-based learning" ( $p$. 7).

Here, and for the remainder of this article I draw upon Alberta as the educational context for understanding new literacies for two reasons: (1) it is the site where the teacher-participant discussed in this article taught (and continues to teach) ELA; where the case-study was conducted, and (2) it is a province that continually renews its commitment to populating classrooms with new interactive technologies. This has been manifested through such initiatives as Emerge One-to-One laptop learning, Technology and high school success, Innovative classrooms and produces classroom-based research publications on these initiatives including iPads: What are we learning and Bring your own device: A guide for schools (Government of Alberta). I propose here that it is through a longitudinal consideration of one ELA teacher's classroom experiences within a jurisdiction that encourages the implementation of new technologies that we can gain a clearer perspective of the ever-changing new technical stuff, and more importantly, the renewable but sustainable ethos required for composing new literacies. Through this examination, we can better understand what is important for teachers to let go of and hold on to in the changing constructs (new technical stuff) and personal/social contexts (new ethos stuff) to encourage a fostering of students' new literacies in ELA classrooms.

\section{Methodology}

\section{The case study}

This article explores, through holistic and long term analysis, a single case drawn from a collective case study in which I examined the ELA classroom experiences of three teacher participants in rapidly changing digital times (Nahachewsky, 2010). In particular, I inquired into the relationship between the teachers' conceptions of literacy and how this impacted their pedagogy and their textual stances within their classrooms. The questions that guided my research included:

(1) What are the classroom experiences of three selected senior ELA educators teaching born-digital students?

(2) How do these teachers' own conceptions of literacy affect their pedagogy?

(3) What stances of textual authority do these teachers have in their classrooms?

Rich data were gathered in each case through the methodological triangulation of on-site classroom observation, face-to-face semi-structured interviews with the teacherparticipants and selected students from their classrooms, and the teachers' online reflective writings in response to two prompts: 
1) What are some of the changes that you have witnessed/experienced during your time as an ELA teacher?

2) What are the contemporary challenges that affect you as an ELA teacher?

Having taught for 17 years and piloted the latest revised curriculum in Alberta, the teacher-participant in this article - Michelle - was known to me, and chosen through purposeful sampling. "The logic and power of purposeful sampling lies in selecting information-rich cases for study in depth. Information-rich cases are those from which one can learn a great deal about issues of central importance to the purpose of the research" (Patton, 1990, p.169). "Information rich" in each of the cases meant that the teachers were practicing ELA classroom teachers. They were not selected in relation to any other criteria including digital expertise. Analysis consisted of making a detailed narrative description of the classroom setting (Stake, 2006), with domain-related categorical aggregation of observation, interview, and writing data leading to issuerelevant themes and meanings for this participant's case. Such research characteristics and approaches encourage an inquisitive rigour, rather than deterministic closure, in the pursuit of understanding the multifaceted realities of contemporary literacy classrooms and their many literacy events.

\section{The new literacies classroom as text}

Understanding teachers' use of the "technical stuff" and "ethos stuff" to compose a new literacies classroom is enhanced by using a metaphor of "classroom as text". The metaphor of ELA classroom as text has been employed previously in relation to reading, or interpreting teachers' classroom organization and pedagogical practices "using terms more typical of literary study than empirical research" (DeFabio 1989, iii). "[T]he metaphor of reading the classroom as text holds both generative and explanatory power (and)... may have some logic for most English teachers given our daily attention to reading and writing texts" (VanDeWeghe \& Reid, 2000, p. 128). Recently, I have used this metaphor to better understand and represent the role of contemporary teachers' classroom practices in my own research and writing (Nahachewsky, 2010; Nahachewsky $\&$ Begoray, 2010). The metaphor of classroom as text - understanding text to include all constructions that form sets of meaning and signifying practices - provides a useful interpretive lens for understanding the role of teachers, and their relationship to learners through pedagogy and textual choice in new literacy classrooms.

In a new literacy classroom (con)text, one should witness teaching and learning, or literacy events that are more "participatory, collaborative, distributed and less expertdominated than the published, individuated, and author-centric conventional literacies" (Knobel \& Lankshear, 2007, p. 9). This relational text is comprised of new technical and ethos stuff including innovative print or post-typographic textual processes and products composed by both the teacher and students through heterogeneous nodes that do not reproduce existing forms and ideas. Here new literacies affect horizontal, rather than topdown, relationships of teacher and student through changes in culture, temperaments, and mind-sets, as well as in technologies (Coiro, et. al., 2008). Descriptions of paradigm cases, such as the one explored in this article, are important then because, "... it is possible to use new technologies to simply replicate longstanding literacy practices - as we see ad infinitum in contemporary classrooms" (Knobel \& Lankshear, 2007, p.7). 


\section{Study data}

The classroom context - The students in Michelle's (pseudonyms used throughout) 8:40 am class are restless in their seats before the first period bell. She's writing on the board: "(1) quiet reading; (2) journals due tomorrow; (3) today Death of a Salesman - sharing our thematic connections." Pages turn and screens flicker. One student checks for text messages while leafing through her print copy of the Play. Another student slips iPod buds into his ears, but also nods at Michelle's oral prompt: "After quiet reading, try to come up with an individual theme statement that represents the understanding you're arriving at."

On a monitor mounted just below the ceiling in a front corner of the classroom, school messages scroll across the screen: "noon-time chess... wiener Wednesday... leadership announcements... open stage improv... Millennium Excellence Awards...compressed schedule...bus passes... trip to Russia...." A student pulls a fitted toque over his close-cropped hair and multiple piercings, looking alternately at his book and the monitor before settling into his copy of the Play.

A girl with low-riding jeans and electric-green highlights in her hair raises her hand. Michelle stops leafing through a file at her desk, moves towards the student, listens and answers: "Become the expert on that aspect of the Play." And then she says, more loudly to the whole classroom of 33 Grade 12 students, "Okay, begin to group up; work with someone you haven't in a while. Later this morning you'll have to share with other groups in the class either your overarching sense of character, conflict or the theme you found. Remember to give key material in support. We'll check-in after 20 minutes." She turns to write these instructions on the whiteboard as the students begin to sort themselves out through their actions, interactions, processes and products. As Knobel and Lankshear (2007) acknowledge, the sheer proliferation of textual types and spaces in Michelle's classroom means that there is always somewhere for students to go to develop their new literacies. To better understand this approach, it is important to know more about the teacher's own ethos through her literacy development.

Michelle's literacy context - At the time of the study, Michelle was in her late 30s and was an ELA specialist with 17 years of teaching experience. She had piloted the revised Alberta English language arts Program of Study [ELA POS] (Government of Alberta, 2003) in her urban public school division. As she stated in our first interview, "I was looking for something new to explore as I had the feeling that I had "been there and done that" with the old curriculum already." She ended up working three years with the piloting committee through Alberta Learning. This committee consisted of people throughout the province who had a draft of the document with the general outcomes. These various classroom teachers worked through the draft document, implementing it into their classrooms through existing resources at that time. Michelle assumed a positive tone when discussing the process and the changes to the recently revised curriculum. "I didn't find it a struggle at all because I felt 'finally', this will fit the students' world." She further held that this revised curriculum acknowledged that:

... students had more life experiences coming in to the classroom. They were willing to challenge what was happening. They weren't as complacent in accepting what the "expert" had to say. As much as people like to say that 
teenagers nowadays are scattered and don't have the classical literature background, they are much more worldly smart than we ever were and they are willing to challenge it and to see what they see in it, and to support that through many different texts and perspectives - from things on the page, to the internet, to their own experiences.

Michelle's early literacy developed while growing up in a family with two sisters, a dad who worked in the Provincial Corrections system, and a mom who was an Elementary teacher. Michelle described herself as a "voracious reader" who literally, from Grade 3 onwards, read everything including the backs of cereal boxes, Archie comics, MAD comics, Judy Blume, The Chronicles of Narnia, The Hobbit, and so forth. This wide array of textual choice continued to the present day. She stated, "reading is valuable to me" although she regretted that the only thing she did not have time to read more deeply was professional literature because "you just get so caught up in doing what you're supposed to be doing in the classroom that you don't often have the time to reflect on what you could be doing." She also commented on her experiences as an ELA student:

The last time the curriculum changed was in 1982. I didn't see a lot of merit in that curriculum as a student because I wasn't good at it - I enjoyed the reading but not the reflective writing and such. And I remember not doing so well in the diploma exam and thinking "well at least that's the end of that". But that also set the tone - for if I were to ever teach, I would never teach that way. So coming back to that same school later as a teacher, where I subbed for a number of years as well as being a middle years teacher, it was a great preparation in the idea that "it's not all about analysis but rather it's about personal connection" - what does this literature mean to you, how can I reflect on it in my own life. Middle years teaching was very much seeing that personal connection, not necessarily the literary merit of something or a hyper-critical analysis.

Michelle worked in a .85 teaching position. This allowed her the time and flexibility she needed to raise her two school-aged children. She stated that she valued her time with her son who was eleven, and her seven year-old daughter. Michelle spoke about her children's literacies. "My son and I have read through the whole Harry Potter series. One book has a great scene at the beginning with the choir singing "toil, toil, burn and bubble..." from Macbeth which we made an immediate connection to, though I don't always verbalize the connections I make while reading with my kids because it would drive them nuts. But there's always something bouncing around in there."

Michelle's textual interactions with her children moved from the page to the screen. "It gets exhausting. It's amazingly exhilarating but also exhausting. You know they're full of questions, and there's never a question that we haven't answered in some way shape or form." She was well versed in TV programs, ads, and video games such as Neo Pets, Zelda, and Fable. Michelle explained the narrative structure and character development for Fable. "You develop characters...every choice you make for your character affects him to become an evil horrible man, a hero, or a magician. So every choice you make within the context of the surroundings affects your strength, your 
emotions, your morals, your ethics and in this way you can better understand who you are as a real person, not only an avatar."

Broadening perspectives of text - The textual variety that developed during her own childhood, and through to her adult life as a parent with her own children, was also evident in her work as a senior ELA teacher. During my on-site visits to her urban high school, we would usually begin in the Humanities workroom, or the "pit", where Michelle would organize her work for the day. Here she navigated and negotiated amongst a broad variety of technologies and texts at her desk space - from cell phone to email, popular culture magazine to online professional journal - before doing the same in her classroom. Her classroom contained whiteboards, a TV with cable, a computer with Internet, a DVD/CD player, and a digital video recorder as well as several conventional print texts such as student-generated collages and sets of novels. Newer "technical stuff" and accompanying multi-media texts that the school's budget did not afford were brought into the classroom by the students, or students were free to move to other areas in the school for access to wired computers and laptops. Students were often working outside the confines of the classroom as Michelle encouraged the personal and social use of differing technologies and texts.

Michelle's colleagues openly acknowledged her "expertise" with a wide array of digital-based texts. During conversations in the Humanities work room ELA and Social Studies teachers asked: "Michelle, do you know of anything that's new online about Macbeth?... Michelle can I borrow this article?... Michelle, tell me about Halo..." Although she was very knowledgeable and always ready with a response for her colleagues, Michelle did not view herself as an expert or authority of new literacies in her ELA classroom.

Sharing authority - Michelle desired to reach all of the students in her class in a "balanced, more horizontal way" through a multiplicity of technologies and text types. These texts were sometimes recommended as a resource by Alberta learning through the Program of Studies, some were chosen by Michelle, while others were chosen by her students throughout the term. The rationale or ethos for this "horizontal" approach to text type and text selection is voiced in her second online journal response:

Teachers, and students in turn, are empowered by openness and trust in the abilities and strengths of each teacher and/or student. No longer is understanding/memorization of the literature the end result, but the broadening of the definition of text/context, the idea of meta-cognition and choices within the creation/study all support the idea that the text(literature) is merely to be the vehicle to teaching "students" and the reaching of the outcomes as outlined in the curriculum.

Michelle viewed herself as a teacher who often digressed, or taught in "tangents" that were initiated, at times, by her students. It was these digressions that I observed during my on-site visits - through textual, conversational, and representational openness - that provided for the ELA senior course's concepts and themes to come in to clearer focus. Through this non-expert and tangential approach, Michelle created a space in the 
classroom; a space for unanticipated texts, ideas, and literate practices to emerge - all of which were vital to engaging her adolescent students and their need for participatory learning.

Within the contact zone (Bakhtin, 1981) of their classroom, textual choices and practices were dialogic. The dialogue she engaged in herself, and that she modeled for her students, encouraged a continual becoming. Students were able to construct and express understanding through platforms beyond and alongside the essay. This openness in textual stance was expressed through new technologies that were not present in the other two sites I observed. Students' use of cell phones and digital video cameras were extensions of themselves and their literacies. In the dialogic space of Michelle's classroom students were more openly able to arrive at understandings of what certain technologies and texts - whether it be novels, text messages, videos, or digital videorecordings - extended or obsolesced (McLuhan, 1988). Networks of constructed understanding were composed between the teacher and her students. Teacher became learner, learners became teachers, readers were writers and writers became readers. Outof-school literacy practice was privileged as in-school practice - both were transferred and became transportable through the various new technical stuff of the classroom, and students' own devices.

Michelle's ability and conscious decision to provide the opportunities for discovery, and help to co-construct new literacies and learning with her students emerged from her broadened stance on textual engagement and interpretation:

I believe that the biggest fights happen when kids say "no, you're wrong" during a discussion. Well who am I to say. Most of the recommended authors are dead by now, and so it's too late to ask them what their writing is about. And if you do if you reflect it's about the wholeness of it; the context... kids should consider that they are right in their interpretation. There is validity to their thoughts and experiences, and they can be the experts if they are thoughtful and insightful about it. It gives them empowerment... for the most part it's that exploration that's the exciting part - the coming to terms with it.

That is, she became a learner alongside her students in their shared literacy development, as opposed to acting as sole disciplinary expert or authority.

Fostering students' critical literacies - Jason and Sasha, the two Grade 12 students whom I interviewed from Michelle's class, discussed the nature of this horizontal relationship and the importance of expanding notions of text in their classroom. Jason was a male student who bussed into school each day from the family farm. During our interview, Jason stated "Mrs. F. (Michelle) helps us to choose good stuff for English, and new stuff - books, movies, websites, conversations - that point you towards something. I think that's the whole point of education, to point you towards something that you wouldn't think of yourself." Jason also noted that the various texts Michelle chose, and how she pointed students in a direction without determining where they would end up, meant that they were better critical thinkers than in other classes. "So that's where the most emphasis is - going beyond just enjoying the story, or movie, or website to 
understanding an underlying message they're (author, director, host) trying to get across; what we can make of those messages."

The second of Michelle's students whom I interviewed was Sasha. She came from a professional household. Her mom was completing her MA in nursing, her dad worked in the Aero-tech industry. She had recently been accepted as a direct entry student into Education at the University of Alberta. Sasha appreciated Michelle's open manner in her teaching. This openness related to Michelle's treatment of her students' ideas as well as engagement through multiple textual formats:

James: What does she bring into this class that you like?

Sasha: In her class we do poetry, current events, pop culture, the media and we talk about our life; we talk about the future and everything in her class. It's not just "Do this, this is what you have to do for the curriculum, essay or exam". One thing that I absolutely love about her class is that tolerance is expected, there is no room for ignorance or arrogance.... Whenever anything like that comes up in Mrs. F's class it's pretty much discussed why someone expressed it that way and then we're done. There's not a lot of negative debate, but rather discussion.

Here, the classroom teacher and her students achieved various understandings and critical abilities in relation to a broad palette of texts, and conversations that formed and informed their composition of the classroom. These conversations emerged in relation to the various personal and professional literacy discourses that Michelle engaged in as a teacher. Michelle stated that, "I try, with shifts to different technologies, texts and literature in culture, to use that with the students. They need that here (at school) too.... We often work through two or three texts and different mediums together - a visual, a print based, something multimedia or a newspaper - something different that all deal with the same theme, and then I ask them to go out and find a message or find those connections in what they're comfortable with; demonstrate how it fits or contrasts with all of those others and bring it back."

Relationships between teacher and students were horizontal, with no one's opinions or perspectives taking precedent over the others. Instead of scarcity, familiarity was encouraged. The same relationship existed between text types - both in those consumed and those created. Michelle encouraged her students to "freely take bits of cultural production that were in circulation and use them to create new ideas, concepts, artifacts and statements, without having to seek permission to re-use, or to be hit with a writ for using particular animation or music sequences as components in remixes" (Lankshear \& Knobel, 2007, p. 12).

Deep critical understandings were built amongst a horizontality of texts, or an intertextuality. These intertextual appropriations (Bakhtin, 1981) amongst the content of various texts and student/teacher discourse were only one aspect of the critical literacy practices evident in this class. Michelle also created spaces within the context of her classroom for multiple forms of student generated textual composition on new technologies alongside the broadening horizon of textual consumption. 
Going beyond - Michelle's ELA class was the only one of my collective case study's three sites in which I observed student produced digital films as a form of expository composition. One of the student-produced films I watched exhibited a clear sense of filmic codes and conventions through the construction of a decidedly postmodern, fastpaced exposition. This eight-minute film, in which both Jason and Sasha along with six other students appeared, presented a message that education is better than violence as a tool to change the way that the world is. This message was communicated through an appropriation of visual and thematic elements from pop culture, advertising, and literary texts. In particular, the students paid homage to their teacher Mrs. F (Michelle) in the film as someone who encouraged them to "love, laugh and learn." This critical discourse was built through a variety of inter-textual references including: a slapstick chase scene that ended with a Lord of the Flies visual reference of a mannequin's head on a stake to demonstrate the horrors of armed conflict; a Brave New World reference to the year 432 AF (After Mrs. F instead of After Ford); and a cut away (Monty Python influence) closeup to a "Lady Gaga" influenced character saying that she was "now a nuclear physicist because of Mrs. F". Through this comedic yet critically informed representation, Mrs. F's participatory and shared-expert (where teacher or students could be expert) pedagogical style was represented as symbolizing the positive and transformative possibilities of "new ideas and sensibilities" over violence.

Composing one's self as teacher in disorienting times - Dimitriadis (2001), drawing from Bakhtin, describes this relationship built upon textual appropriation and teacher/student discourse as "a proliferating flow of text and activity that is continually reconstituted through tensions and transactions between the lines of flight and the lines of articulation that make it up" (p. 189). Michelle, although expressing in one interview that "I don't always know what to hold on to and what to let go of in the classroom... at times it's disorienting," worked alongside her students in the daily tensions and affordances of a rapidly expanding multi-media and digital universe. She struck an open stance in the classroom, having a theoretical grounding in both the possibilities and complications of broadening notions of literacy and text, especially as they were defined in the Alberta ELA Program of Study.

The co-authorship of the classroom, including Michelle's encouragement of experiential, inquiry-based learning along with a flexible textual stance, could be understood to remove some of the disorientating pressures from Michelle's new literacy teaching experiences. Engaging students on various levels - through a multiplicity of texts and compositional forms from dialogue to digital video - provided spaces for the development of Michelle's and the students' literacy and learning in ever-changing times. When I asked Michelle where she came up with her teaching ideas, she replied that she had a great deal of print-based materials that I had observed in the humanities work room, as well as internet searches, discussions with other teaching staff, student teachers, and professional development opportunities. But she reiterated, in our final interview, "one of the greatest resources for ideas are the students themselves, they are constantly challenging me, suggesting activities, revisions, texts to study and so on."

Within these competing and complementary spaces, and perhaps because of her willingness to share textual authority in the classroom, Michele had a sense of proportion and wellbeing as an ELA teacher in the digital age: 
I just really found my place in the English classroom, not so much from the position - I don't see myself as the expert - I'm grammatically incorrect throughout my conversations in class, I get up in front of the whiteboard and I question my spelling - which allows me, I don't see this as a weakness but as an acknowledgement that it allows the students to understand that they're growing with me. I am the facilitator in the class, not the expert and they're welcome to bring in different areas and ideas as long as it is well supported.... I wish I had a "slow down" control on my brain but it doesn't work. So that sense of business people who talk about multi-tasking - I kill myself laughing because they have nothing on teachers. I try, with the shifts in different texts and literature, and the students need to do that too. Their lives are like that very much as well - but I digress...

Michelle did not feel isolated as a teacher, or that she had to "do it all". She felt a part of an active community of learners and professionals who facilitated the co-authoring of her classroom, and teaching experiences in a digital age. In these rapidly changing times, she reminded herself of the value of her work - that it would sometimes, but not always immediately be evident in the students' growth as a composer or consumer of texts whether it be through classroom conversations, small group work, in print or online response journals, digital videos, essays, posters or poetry.

These classroom literacy events as paradigm case - Britzman (2003) writes, "teaching and learning have multiple and conflicting meanings that shift with our lived lives, with the theories produced and encountered, with the deep convictions and desires brought to and created in education, with the practices we negotiate, and with the identities we construct" (p. 32). Learning to teach in recent digital-informed times entails a process of becoming: a time of formation and transformation, of scrutiny into what one is doing, and who one can become. Kajder (2010) argues: "New literacies, new technologies, new ways of reading and writing.... In real ways these are invitations to rethink and reimagine our work as English teachers, as readers, as writers and as individuals who have our own literacy identities" (p. 10).

As discussed above, paradigm cases include new literacies that are more participatory, collaborative, distributed and less expert-dominated than the published, individuated, and author-centric conventional literacies. Although Michelle often privileged novels and plays in her senior ELA class, she also had the new technical stuff (recall the video monitor with the scrolling school announcements, the students who would slip iPod earbuds into their ears, cell phones used beside novels, and the student group who used digital video to compose representations rich in inter-textual and multigenre references) and new ethos stuff (a shared-expert approach, collaboration, and participation) of a "paradigm case" (Knobel \& Lankshear, 2007). She encouraged tangential pedagogy and open textual stances - a co-authoring of the ever-changing (con)text of the ELA classroom. Here one can understand how new literacies do affect evolving relationships of teacher and learner. 
Reading Michelle's new literacies classroom as a text - Street and Lefstein (2007) note that "... literary theorists and educationalists have tended to look at literacy in terms of the texts that are produced and consumed by literate individuals" (p.45). One could consider the classroom in this study as a text that could be read physically (DiFabio, 1989; VanDeWeghe \& Reid, 2000). As a physical text, the design of her classroom exhibited different modes of communication including the linguistic - visual, acoustic and spatial. A "reading" of the class demonstrated new technical elements such as a video screen with scrolling school announcements, a TV/DVD cart, student-composed digital poster representations on the walls, iPods and smart phones placed beside copies of plays and novels on the classroom tables which were organized in a semi-circle. In this reading we can understand how Michelle and her students were accessing available design in their appreciation and understanding of written, visual, and acoustic texts.

One could also, as I did, read the classroom as a text composed of relationships of teacher and learner involved in the composition of a new ethos (expressed through new texts and technologies) in that literate place. In that manner, instead of asking, as Fish (1980) did: "Is there a text in this class?" one could very well now ask "Whose text is this class?" Understanding how these new relational and textual processes occurred - the experiences of Michelle teaching in digital times - and how they relate to broader social/educational structures from which they emerged, is significant in a time of tremendous change for teachers and students in formal and informal educational settings.

\section{Findings from this paradigm case}

New literacies studies "provide conceptual, theoretical, and methodological shape for an emerging field without unduly foreclosing on potentially valuable perspectives and epistemological approaches" (Coiro, Knobel, Lankshear, \& Leu, 2008, p. xii). Such an approach allows for an inquiry into, and understanding of particular literacy practices through interdisciplinary lenses within a broad and rapidly changing personal or social communications context. Adopting the metaphoric lens of classroom as text and teacher as author provides a useful reference point for understanding situated events within the broader discipline. In composing the new literacies classroom, three themes emerge from the holistic case study data presented above: (1) the need to co-author new literacies events; (2) teaching in a new literacies classroom becomes an ellipsis; and (3) reciprocal relationships form between teacher and learner(s). These findings are discussed in more detail below.

The need to co-author new literacies classroom - Besides the embedded digital technologies in her class, what was also "visible" was Michelle's sharing of classroom authority. Michelle spoke of her teaching as providing a choice; of text as a starting point. She became invigorated by her students' creativity when she altered, not the goals, but the form of the multimodal responses her students could create. Clearly, single authorial/ authoritative stances including mandated selection of textual formats and responses, can be de-emphasized in contemporary classrooms.

It was evident throughout Michelle's case that she worked to acknowledge her students' voices and perspectives as co-authors in their ELA classroom. She believed, working within the changed ethos of the Alberta Program of Studies, that there was a historically unique opportunity to engage in a horizontal relationship between teacher and 
students, and students and text. That is, no one person or text held authority, or positioned themselves as having a final correct answer, over any other.

Michelle had made a conscious decision to co-author the space of her classroom with her students to facilitate access to multiple literate processes and texts. She expressed that there was "too much stuff" to ever get around to using, and that the students provided her with many of her best language learning activities and sources. Michelle consistently trended towards a co-authoring of her classroom in response to the ever-expanding array of textual platforms, genres, and forms of writing and representation that her students engaged in - both inside and outside of school spaces. "Adolescents are increasingly finding their own reasons to become literate, especially when learning a literate practice allows them to collaborate with and participate within a group that values their knowledge/ contribution" (Kajder, 2010, p.10).

Although meaningful in particular contexts of composition and learning, the modernist notion of single authorship/authority needs to be revisited when considering the wide array of writing and representational possibilities for teachers and students in this digital-informed age. As Michelle wrote in her second online journal entry, "It is in this way that both the students and teachers are powerful within the classroom." What becomes evident through the holsitic analysis of data from this case is that neither the teacher nor the students can rest on any previously privileged sense of literacy and learning, and that much can be accomplished through the co-authoring of literate selves.

New literacy teaching becomes an ellipsis - "I don't always know what to hold on to and what to let go of in the classroom." This quote from Michelle is more of a question than a statement. Such an ethos of inquiry is vital to understanding teaching in contemporary ELA classrooms. The present verb tenses are particularly important here. Through them we understand that Michelle is continually in the midst of "becoming" a teacher in the decisions and actions required for each situated classroom literacy event. This is troubling for those who view literacy, learning, and teaching as conventional fixed phenomena like print on a page - published, individuated, and author-centric. For Michelle, this constant decision-making, and continual becoming helped her to be openin new reading and compositional possibilities - rather than declarative in fostering her students' own emergent literacies.

Young people in this digital generation expect a participatory culture (Jenkins, et al., 2006; Palfrey \& Gasser, 2008). Conventional containers for language arts composition such as author studies, research essays and poetry critique do not hold with students who expect experiential and social learning with a distributed audience. The participatory nature of contemporary digital culture encourages learners to create and distribute new typographic and post-typographic content. Authentic audience fuels their creativity, not standardized tests or rubrics. Realizing this reality of new literacies teaching and classrooms, Michelle began to let go of certain texts and practices that she saw as part of an approach forwarded in the previous curriculum - one of adult-driven agendas instead of youth-driven social engagement and sharing (Ito, 2008). McLuhan (1988) considered such actions to emerge in the resonating time of a new technology or text. As the user(s) of the new technology/text extend their senses through that artifact, they consider alternately personal and broad implications, such as what is being lost or gained through that text/technology. 
There was a daily negotiation by Michelle - what to include or exclude for each literacy event - in terms of the texts and pedagogy she employed. This can be likened to an ellipsis in the (con)text of the new literacies classroom. Grammatically, an ellipsis represents the omission of a word or words necessary for complete construction but understood in context, and the sign (...) that something has been left out of a quotation. As a narrative device, an ellipsis is the omission of a portion of the sequence of events, allowing the reader to fill in the narrative gaps.

For Michelle, leaving gaps for her students to choose how they would represent their constructed understanding - such as the digital video - in relation to core texts amidst a broadening horizon of peripheral text was empowering for both her as a teacher and her students. As in Miller's (2007) inquiry, Michelle found that when teachers have the ethos to let students explore their literacies through new technical stuff these "embodied multimodal literacy tools...became agents of change" (p. 78). The new ethos stuff and new technical stuff encouraged a change not only in her students, but also in Michelle's own understanding of literacy and text in a new teacher/learner relationship.

Realizing reciprocal relationships - McClay (2007) states, "new literacy environments allow relationships with unclear or no delineation of conventional boundaries, and many traditional literacy boundaries do not hold in traditional ways." Through the personal and social spaces of digitally afforded new literacies, Livingstone (2008) has found that what engages young people "is primarily the peer-to-peer opportunities...in which they provide for each other the responsiveness, criticism, humour, feedback, openness, and networking that so often is absent from content designed for children by adults" (p. 116). As Michelle opened up her classroom to a co-authorship with her students and an ellipsis in textual selection (both in consumption and composition), she experienced a reciprocal relationship with her students. Not only did they open to new potentials in their own literacy development, they also "schooled" Michele in the texts and textual practices that were most important to them and their new literacies.

Noted above, new literacies affect horizontal, rather than top-down, relationships of teacher and student through changes in culture, temperaments, and mind-sets, as well as in technologies (Coiro, Knobel, Lankshear, \& Leu, 2008). Throughout the study, it was evident to Michelle that her pedagogical and textual choices held direct implications for her students' emergent language and literacy learning processes. But what became as important, were the ideas that the students brought to bear on the texts and textual engagements through new technologies, and how these were integrated into the composition of the classroom.

It became this teacher's role to encourage her students to develop a voice through the texts that they composed, and connections they made to their lives beyond the page, screen, or classroom. In turn, the students influenced Michelle's conceptions of what it means to be literate, and what texts are meaningful to language learning. Knobel and Lankshear (2007) write of this as a "familiarity", rather than a "scarcity" model.

The implication here is that people who bring a scarcity model of value with them... will act in ways that diminish rather than expand potential. For example, applying certain kinds of copyright and permissions restrictions to the use of information may constrain the dispersal of that information in ways that 
undermine its capacity to provide a basis for relationship. This will, in turn, undermine the potential of that information to work as a catalyst for generating creative and productive conversations, the development of fruitful ideas, the emergence of effective networks, and so on... (p. 11).

It was through such a familiarity model, or reciprocal teacher/learner relationship that situated moments became part of an ongoing dialogue in the co-construction of word and literate world that was valued by this teacher and her students. The kind of value that Lankshear and Knobel (2007) see as appropriate to new literacies classrooms which "maximize relationships, conversation, networks and dispersal" (p. 11).

\section{Educational implications of this holistic case}

As noted at the beginning of this article, Leander (2008) suggests, "now we [in new literacy studies] are ready to move onto an even more difficult concept: How do we think about the everyday?" (p. 33). Data and findings from this article's holistic case study add empirical evidence and understandings for a consistently under-represented frame of reference - the secondary ELA classroom. Here teachers are required to navigate language learning relationships amongst their students, subject area curricula, continually shifting communications practices, and their own conceptions of literacy. Situated literacy moments happen quickly and continuously, while significant change to literacy instruction seems to occur slowly within the ELA classroom. But change is needed. Complications emerge from subject area curricula that struggle to adequately bridge conventional conceptions of text and literacy to new literacies. Complexities also emerge as teachers struggle to find meaningful texts and textual practices to engage their students while seeking equilibrium amongst print-based and digital-based literacies.

As was evident in this case study, such struggles can create a sense of disorientation, but also tangible pedagogical and textual possibilities for ELA teachers. The daily practices within paradigm new literacy events in classrooms such as Michelle's provide a rich perspective to better understand responses to broader changes in education including provincial literacy initiatives, as well as changing student and teacher demographics. Understanding of teachers' own literacies, and shifts in teachers' textual stance and pedagogy as witnessed in the study - to a co-authorship and ellipsis - are essential if we are to address the many complexities of teaching ELA in contemporary times. These shifts become increasingly pertinent while provincial jurisdictions such as Alberta continue to unfold a cascade of ever-changing technological initiatives (smartboards, iPads and the like) into the classroom and focus on what the student can bring both technically and in ethos - through personalized learning in the $21^{\text {st }}$ century.

The paradigm case in this article can also inform tertiary educators' engagement with their own students as pre-service teachers. New literacies have become "the everyday" with rapid adoption of iPads, eBooks, social networking and the like in university teacher education programs. The consideration of what we as literacy educators should hold on to, and what we can let go of, continues to grow in its importance. Further classroom-based empirical inquiries then, such as the one presented in this article, are vital to present and future literacy education. For as has become evident throughout this article, contemporary ELA classroom new literacies and learning are only as vital as the students and teachers who compose them. 
References

Bakhtin, M. (1981). The dialogic imagination: Four essays. Austin: University of Texas Press.

Britzman, D. (2003). Practice makes practice. New York, NY: Longman.

Coiro, J., Knobel, M., Lankshear, C., \& Leu, D. (2008). Handbook of research on new literacies. New York, NY: Erlbaum.

DiFabio, R. (1989). Classroom as text: Reading, interpreting and critiquing a literature class. Report for Center for the Learning and Teaching of Literature, (pp. 1-28). Albany, NY: University of Albany.

Dimitriadis, G. (2001). Performing identity/ Performing culture: Hip hop as text, pedagogy, and lived practice. New York, NY: Lang.

Fish, S. (1980). Is there a text in this class? The authority of interpretive communities. Cambridge, MA: Harvard UP.

Government of Alberta. (2003). Senior ELA POS. Retrieved from http://education.alberta.ca/teachers/program/english/programs.aspx

Government of Alberta. (2012). Technology in Schools. Retrieved from education.alberta.ca/admin/technology.aspx.

Ito, M., Horst, H., Bittanti, M., Boyd, D., Herr Stephenson, B., Lange, P., Robinson, L. (2008). Living and learning with new media: Summary of findings from the Digital Youth Project. Cambridge, MA: MIT Press.

Jenkins, H., Clinton, K., Purushotma, R., Robinson, A., Weigel, M. (2006). Confronting the challenges of participatory culture: Media education for the $21^{\text {st }}$ century. The John D. and Catherine T. MacArthur Foundation. Retrieved from http://digitallearning.macfound.org/...JENKINS_WHITE_PAPER.PDF.

Kajder, S. (2010). Adolescents and digital literacies: Learning alongside our students. Urbana, IL: National Council of Teachers of English.

Kamberelis, G., \& Dimitriadis, G. (2004). On qualitative inquiry: Approaches to language and literacy research. New York, NY: Teachers College Press.

Knobel, M., \& Lankshear, C. (2007). A new literacies sampler. New York, NY: Lang.

Lankshear, C., \& Knobel, M. (2006). New literacies: Everyday practices and classroom learning. $\left(2^{\text {nd }}\right.$. ed). New York, NY: Open University Press.

Larson, L. (2012). It's time to turn the digital page: Pre-service teachers explore eBook reading. Journal of Adult \& Adolescent Literacy. 56(4). 280-290.

Leander, K. (2003). Writing travelers' tales on new literacy landscapes. Reading Research Quarterly, 38(3), 392-197.

Leander, K. (2004). Reading the spatial histories of positioning in a classroom literacy event. In K. Leander \& M. Sheehy (Eds.), Spatializing literacy research and practice (pp. 115-142). New York, NY: Lang.

Leander, K. (2008). Toward a connective ethnography of online/offline literacy networks. In J. Coiro, M. Knobel, C. Lankshear \& D. Leu (Eds.), Handbook of research on new literacies (pp. 33-65). New York, NY: Erlbaum.

Leu, D., Kinzer, C., Coiro, J., \& Cammack, D. (2004). Toward a theory of new literacies emerging from the Internet and other information and communication technologies. In R. Ruddell \& N. Unrau (Eds.), Theoretical models and processes 
of reading (5th ed., pp. 1570-1613). Newark, DE: International Reading Association.

Lewis, C. (2007). New literacies. In M. Knobel \& C. Lankshear (Eds.), A new literacies sampler (pp. 229-237). New York, NY: Lang.

Livingstone, S. (2008). Internet literacy: Young people's negotiations of new online opportunities. In T. McPherson (Ed.), Digital youth, innovation, and the unexpected (pp. 27-39). Cambridge, MA: MIT Press.

McClay, J. (2007). “Look, Ma, no boundaries!” Relationships in new literacies learning and teaching. English Practice. Retrieved from http://www.bctela.ca/resources/english-practice/spring2007/

McLuhan, M., \& McLuhan, E. (1988). Laws of media. Toronto, ON: University of Merchant, G. (2008). Digital writing in the early years. In D. Leu, J. Coiro, M. Knobel, \& C. Lankshear (Eds.), The handbook of research on new literacies (pp. 751-774). New York, NY: Erlbaum.

Merchant, G. (2008). Digital writing in the early years. In D. Leu, J. Coiro, M. Knobel, \& C. Lankshear (Eds.), The handbook of research on new literacies (pp. 751-774). New York, NY: Erlbaum.

Miller, S. (2007). English teacher learning for new times: Digital video composing as multimodal literacy practice. English Education, 40(1) 61-83.

Moje, E., Overby, M., Tysvaer, N., \& Morris, K. (2008). The complex world of adolescent literacy: Myths, motivations, and mysteries. Harvard Educational Review, 78(1), 107-154.

Nahachewsky, J. (2003). Reading the writer: Multilayered literacy experiences in an online senior language arts classroom. (Unpublished master's thesis). University of Saskatchewan, Saskatoon.

Nahachewsky, J. (2005). Expanding notions: A perspective on the challenges facing contemporary language arts teachers. English Quarterly, 37(1), 22-26.

Nahachewsky, J. (November, 2007). Teaching at the edge of Reason: E-Learning. 4(3), 367-375.

Nahachewsky, J. \& Slomp, D. (2009). Sound and fury: Studied response(s) of curriculum and classroom in digital times. In J. Nahachewsky \& I. Johnson (Eds.), Beyond "presentism": Re-imaginging the historical, personal and social places of curriculum. (pp. 139-151). Rotterdam, The Netherlands:

SensePublishers.

Nahachewsky, J. (2010). At the edge of reason: Teaching language and literacy in a Digital Age. (Unpublished doctoral dissertation). University of Alberta, Edmonton.

Nahachewsky, J. \& Begoray, D. (November, 2010). Authoring the Textual Classroom in Digital Times. Changing English Studies in Culture and Education, 17(4), 421430.

Nahachewsky, J. (2012). Changing pathways: Investigating the impact of e-Readers on students' new literacies. Paper presentation for: Literacy Research Association Annual Conference: San Diego.

Palfrey, J., \& Gasser, U. (2008). Born digital: Understanding the first generation of digital natives. New York, NY: Basic Books/Perseus.

Patterson, S., Bennet-Stokes, D., Siemens, R., \& Nahachewsky, J. (2010). Enacting 
change; A study of the implementation of e-readers and an online library in two Canadian high school classrooms. LIBER quarterly. 20(1), pp.66-79.

Patton, M. (1990). Qualitative evaluation and research methods. Thousand Oaks, CA: Sage.

Sperling, M. (2004). Is contradiction contrary? In A. Ball \& S. Freedman (Eds.), Bakhtinian perspectives on language, literacy, and learning (pp. 232-251). Cambridge, England: Cambridge University Press.

Stake, R. (2006). Multiple case study analysis. New York, NY: The Guilford Press.

Stagg-Peterson, S., \& McClay, J. (2007). Teaching writing in five Canadian provinces: A new literacies analysis. E-learning, 4(3), 367-375.

Street, B., \& Lefstein, A. (2007). Literacy: An advanced resource book. New York, NY: Routledge.

VanDeWeghe, R., \& Reid, L. (2000). Reading the classroom as text: A heuristic for classroom inquiry. English Education. 32(2), 127-140.

Author Biography

James Nahachewsky $(\mathrm{PhD}, \mathrm{U}$ of Alberta) spent several years as a middle years and high school language and literacy classroom teacher in Saskatchewan. He is presently Assistant Professor in the Faculty of Education at the University of Victoria teaching and researching in the areas of new literacies and curriculum theory. 